\title{
PENDAMPINGAN KEWIRAUSAHAAN RIAS PENGANTIN SEBAGAI PENINGKATAN KEMANDIRIAN EKONOMI PESANTREN DAN SANTRI PONDOK PESANTREN MIFTAHUL ULUM KABUPATEN JEMBER
}

\author{
Oleh: \\ Akhamd Haryono1, Ika Barokah Suryaningsih², Samudji ${ }^{3}$, Fariz Kustiawan Alfarisy ${ }^{4}$ \\ ${ }^{1}$ Fakultas Ilmu Budaya, Universitas Jember
}

aharyono.sastra@unej.ac.id

\begin{abstract}
Abstrak
Kabupaten Jember merupakan salah satu kabupaten yang didominasi oleh pesantren. Mayoritas sosok seorang kiyai merupakan seorang tokoh yang juga memiliki pengaruh besar terhadap perkembangan kehidupan saat ini. Miftahul Ulum merupakan pondok pesantren yang terletak di Desa Sidomukti, Kecamatan Mayang, Kabupaten Jember. Kendala yang dihadapi saat ini adalah terbatasnya jumlah tata rias di Desa Sidomukti dan harus mendatangkan dari daerah lain. Tujuan dari kegiatan pengabdian ini adalah meningkatkan jiwa kewirausahaan santri melalui tata rias guna untuk meningkatkan pendapatan dan keterampilan santri di pondok pesantren. Pelaksanana pengabdian dilakukan dari Bulan Agustus - November 2020 di Pondok Pesantren Miftahul Ulum. Metode pelaksanaan pengabdian terdiri dari beberapa tahapan yaitu 1) survei lokasi, 2) FGD (Focus Group Discussion), 3) Pendampingan dan pelatihan, serta 4) monitoring dan evaluasi. Ketercapaian hasil pengabdian ini dapat dilihat bahwa santri putri dapat memiliki rasa percaya diri dalam melakukan tata rias. Oleh karena itu tujuan jangka panjang adalah dapat mencetak lapangan pekerjaan untuk dirinya sendiri melalui tata rias pengantin. Hasil pengabdian dapat menstimulus para santriwati untuk meningkatkan keterampilan dan kemampuan praktik dalam tata rias pengantin.
\end{abstract}

Kata Kunci: pengantin, tata rias, pesantren.

\section{Abstract}

Jember Regency is one of the districts that is dominated by Islamic boarding schools. The majority of the figures of a kiyai are figures who also have a major influence on the development of life today. Miftahul Ulum is a boarding school located in Sidomukti Village, Mayang District, Jember Regency. The obstacle currently faced is the limited amount of make-up in Sidomukti Village and must be imported from other areas. The purpose of this service society is to improve the entrepreneurial spirit of the student through make-up in order to increase the income and skills of the student at the Islamic boarding school. The service was carried out from August - November 2020 at the Miftahul Ulum Islamic Boarding School. The service implementation method consists of several stages, namely 1) site survey, 2) FGD (Focus Group Discussion), 3) Mentoring and training, and 4) monitoring and evaluation. The achievement of the results of this service can be seen that female students can have confidence in doing make-up. Therefore the long term goal is to be able to create jobs for himself through bridal make-up. The results of the service can stimulate the students to improve their skills and practical abilities in bridal make-up

Keywords: bride, make-up, islamic boarding schools

\section{PENDAHULUAN}

Pesantren merupakan salah satu lembaga pendidikan yang identik dengan kegiatan keagamaan untuk bekal pengetahuan santri tentang agama. Jawa Timur merupakan salah satu propinsi dengan jumlah pondok

pesantren terbanyak di Indonesia. Bahkan saat ini pondok pesantren modern di perkotaan juga bermunculan baik untuk kalangan pelajar dan mahasiswa (Machsum, 2013). Secara historis bahwa pesantren merupakan bukti dari perjuangan pergerakan islam di Indonesia (Sayono, 2010).

Baru-baru ini disadari atau tidak bahwa keberadaan pondok pesantren juga mempengaruhi pergerakan sosial ekonomi. Menurut (Ryandono, 2018) bahwa hasil penelitian telah mengidentifikasi pengaruh dari peran dari pondok pesantren dalam pemberdayaan sosial ekonomi di Jawa Timur. Pondok pesantren yang telah maju dapat menciptakan start up (bussines) secara mandiri karena potensi dari santri yang telah dididik 
dalam waktu tertentu. Adapun beberapa profesi dari luaran pendidikan di pondok pesantren bisa menjadi tenaga administrasi dan pengajar baik diluar maupun didalam pondok. Menurut (Widodo dan Nugroho, 2014) bahwa kewirausahaan dilingkungan pesantren menjadi terobosan terbaru dalam mengurangi meningkatkan jumlah pengangguran.

Pondok Pesantren Mifathul Ulum merupakan salah satu Pondok Pesantren yang ada di Kabupaten Jember. Tipologi masyarakat disekitar pesantren mayoritas terdiri dari suku madura. Tahun 2019 tim pelaksana telah melakukan pelatihan wirausaha potong rambut pada santri putra. Sedangkan pada kesempatan ini tim memberikan pengabdian dan pendampingan untuk santri putri melalui kegiatan tata rias pengantin di pondok pesantren Miftahul Ulum. Tentunya hal ini dapat meningkatkan keterampilan santri dan menumbuhkan jiwa wirausaha untuk masyarakat sekitar. Tujuan dari pengabdian ini adalah meningkatkan jiwa dan semangat santri dalam berwirausaha melalui keterampilan tata rias pengantin yang potensial dibutuhkan dan dikembangkan di tempat domisili masing-masing. Serta memberikan akselerasi pesantren dalam hal inovasi mendidik santri.

\section{METODE}

Pelaksanaan pengabdian kepada masyarakat melalui skema hibah Program Pengabdian Kemitraan dilakukan di Pondok Pesantren Miftahul Ulum yang diasuh oleh K.H. Abdul Waris. Pengabdian dilakukan pada 14 Agustus 30 November 2020. Adapun dari metode pelaksanaan dari kegiatan ini sebagai berikut:

Survei lokasi pengabdian: Tim pelaksana pengabdian melakuan survei terlebih dahulu untuk melakukan koordinasi kegiatan. Survey dilakukan oleh Tim dari Universitas Jember ke lokasi pengabdian untuk mengidentifikasi potensi dan pengembangan sumber daya yang berkelanjutan pada lingkungan pesantren. Dalam hal ini tim juga mengaksesi sarana dan prasarana pondok pesantren Miftahul Ulum.

FGD: Setelah melakukan koordinasi dengan Tim dari Universitas Jember dan pengasuh Pondok Pesantren Miftahul Ulum, maka dilakukan FGD (Focus Group Discussion) tentang kewirausahaan dalam lingkungan pesantren. FGD tersebut bertujuan untuk memotivasi para santri yang memiliki keterampilan dalam hal tata rias. Dalam kegiatan FGD ini dihadiri oleh pengasuh putri, santri putri, dan TIM dari Universitas Jember. Kewirausahaan dalam lingkungan pesantren dibutuhkan untuk meningkatkan ekonomi dan kemandirian pesantren dalam mencetak santri yang berakhakul Qarimah serta dibekali dengan keterampilan khusus yang dapat meningkatkan pendapatan ketika telah lulus dari pendidikan pesantren.

Pendampingan dan Pelatihan: Setelah dilakukan kesempatan dalam urun rembug tentang pelatihan rias pengantin pada santri putri. Pada kesempatan ini juga diberikan teknikteknik dalam melakukan tata rias. Tim dari Universitas Jember telah mendatangkan pakar atau ahli dalam tata rias yang bisa memberikan ilmu praktis terkait bagaimana merias dengan baik dan benar.

Monitoring dan evaluasi: Tim dari Universitas telah berkomitmen untuk membantu dan memberikan layanan dalam inovasi untuk meningkatkan kemandirian dan pengembangan pondok pesantren. Tim telah berkomitmen untuk menjadi fasilitator apabila terdapat permasalahan dan sesuatu yang ingin dicapai bersama antara pelaksana kegiatan dan mitra. Untuk menindaklanjuti program maka diakhir kegiatan dilakukan survei menggunakan kuisioner untuk mengetahui respon dan identifikasi kendala yang dihadapi oleh target pengabdian.

\section{HASIL DAN PEMBAHASAN}

Berdasarkan hasil pengabdian (Haryono, 2019) santri putra telah berhasil memiliki keterampilan dalam hal potong rambut. Berdasarkan tipologi dari masyarakat disekitar pondok pesantren. Untuk melakukan potong rambut harus menempuh jarak yang lumayan jauh. Jumlah ahli dalam potong rambut disekitar pondok pesantren sangat terbatas. Tidak hanya itu khusus untuk santri putra kerapian rambut menjadi bagian dari kedisiplinan yang dibentuk oleh pengasuh pondok pesantren. Pendampingan keterampilan potong rambut di Pondok Pesantren Miftahul Ulum sangat memberikan dampak yang positif terutama pada aspek kewirausahaan.

Pada kesempatan ini di tahun 2020 tim kembali melakukan pengabdian pada Pondok Miftahul Ulum. Namun sasaran pada kesempatan ini adalah santri putri. Umumnya masayarakat desa setelah lulus dari pendidikan pondok pesantren, santri putri telah siap untuk dipinang. Kendala yang dihadapi adalah ketika melangsungkan pernikahan harus mendatangkan ahli tata rias dari daerah lain. Tidak hanya itu biaya yang harus disiapkan juga tidak murah karena faktor jarak dan kemudahan akses juga diperhitungan. Oleh karena itu tim dengan 
sungguh-sungguh memberikan pelatihan dan pendampingan untuk santri putri dalam mengasah keterampilan dalam hal tata rias.

Santri putri dibekali ilmu bagaimana teknikteknik dasar dalam hal tata rias untuk pengantin. Jika ada kegiatan pernikahan tidak perlu mendatangkan dari daerah lain. Santri putri Miftahul Ulum telah diberikan kursus dan pendampingan untuk tata rias. Dalam jangka panjang, santri dapat melatih diri untuk secara mandiri praktek tata rias terhadap dirinya sendiir sampai memiliki kepercayaan diri untuk berani merias oerang lain.

Pada gambar 1 merupakan TIM dari pelaksana pengabdi melakukan FGD (Focus Group Disucussion) yang dihadiri oleh pengasuh miftahul ulum, santri putri, dan mendatangkan ahli tata rias. Santri putri sangat antusias dalam mengikuti kegiatan ini. Pada kondisi mula mula santri belum mengetahui bagaimana teknik tata rias yang benar. Sejauh ini santri hanya melakukan rias wajah secara sederhana. Pada kesempatan ini pula santri dibekali motivasi dalam meningkatkan jiwa wirausaha melalui rias pengantin.

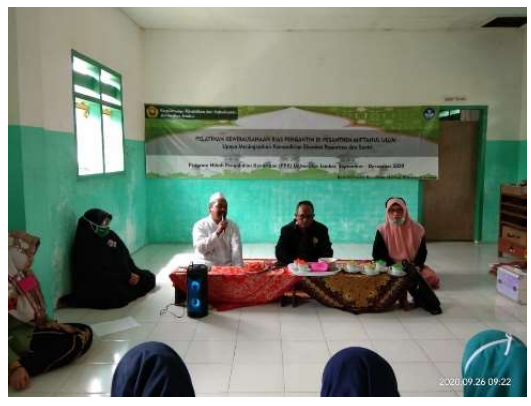

Gambar 1. Kegiatan FGD (Focus Group Discussion) di Pondok Pesantren Miftahul Ulum.

Pada gambar 2 di bawah ini menjelaskan bahwa para santri putri sangat antusias untuk belajar tata rias. Para santri didampingi oleh pakar tata rias yang didatangkan khusus untuk membantu santri dalam melakukan tata rias. Teknis pelaksanaan pendampingan dilakukan dengan action practice. Artinya santri diberikan kebebasan dalam melakukan tata rias berdasarkan rasa (feel) dan tingkat kepercayaan diri (confident) masing-masing santri.

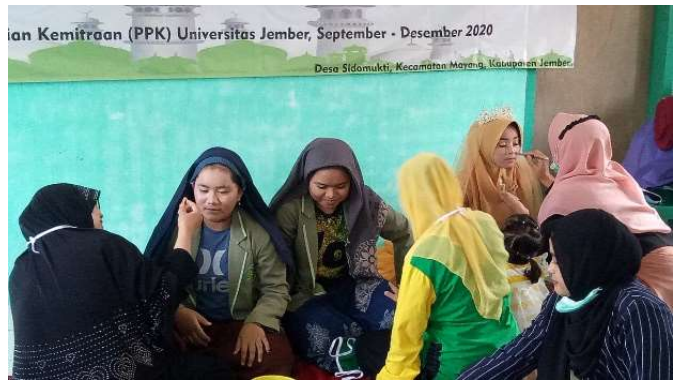

Gambar 2. Praktek dan pendampingan tata rias di Pondok Pesantren Miftahul Ulum.

Pada gambar 3 di bawah ini merupakan hasil dari kegiatas tata rias karya dari santri putri yang didampingi oleh pakar tata rias. Hal yang bisa dirasakan oleh Tim adalah santri dapat meningkatkan keterampilan tata rias ini dalam waktu yang singkat. Hal ini dikarenakan bahwa sebelumnya di Pondok Pesantren ini belum ada kegiatan pengabdian yang mengasah kemampuan dari santri. Santri putri sangat senang dalam kesempatan ini yang mula-mula santri putri belum percaya diri dalam melakukan rias pada wajah. Namun setelah dilakukan kegiatan pendampingan santri putri mulai tergugah semangatnya untuk terus belajar dalam hal rias pengantin.

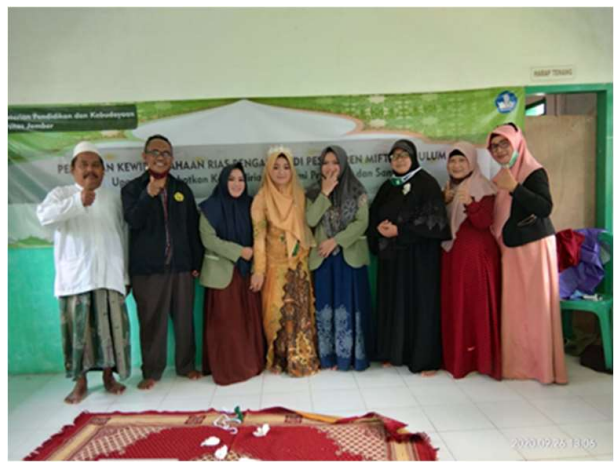

Gambar 3. Proses kegiatan pengabdian rias pengantin di Pondok Pesantren Miftahul Ulum.

Pada tabel 1

merupakan data umum sederhana karakteristik responden pada program pengabdian di Lingkungan Pesantren. 
A) B. D] Vol.7 No.1 Juni 2021, Hal. 65-68

\begin{tabular}{|c|c|c|c|}
\hline $\begin{array}{l}\mathrm{N} \\
\mathrm{O}\end{array}$ & \multicolumn{2}{|c|}{ Karakteristik } & $\begin{array}{c}\text { Jumlah } \\
\text { Responden }\end{array}$ \\
\hline \multirow[t]{3}{*}{1} & Umur & $\begin{array}{l}10-15 \\
\text { Tahun }\end{array}$ & 10 \\
\hline & & $\begin{array}{l}16-20 \\
\text { Tahun }\end{array}$ & 15 \\
\hline & & $\begin{array}{l}\text { Diatas } 21 \\
\text { Tahun }\end{array}$ & 5 \\
\hline \multirow[t]{3}{*}{2} & $\begin{array}{l}\text { Tingkat } \\
\text { Pendidika } \\
\mathrm{n}\end{array}$ & $\begin{array}{l}\text { Ml } \\
\text { (Madrasah } \\
\text { lbtidaiyah) }\end{array}$ & 8 \\
\hline & & $\begin{array}{l}\text { MTS } \\
\text { (Madrasah } \\
\text { Tsanawiyah } \\
\text { ) }\end{array}$ & 13 \\
\hline & & $\begin{array}{l}\text { MA } \\
\text { (Madrasah } \\
\text { Aliyah) }\end{array}$ & 9 \\
\hline 3 & \multicolumn{2}{|c|}{ Jumlah Responden } & 30 \\
\hline
\end{tabular}

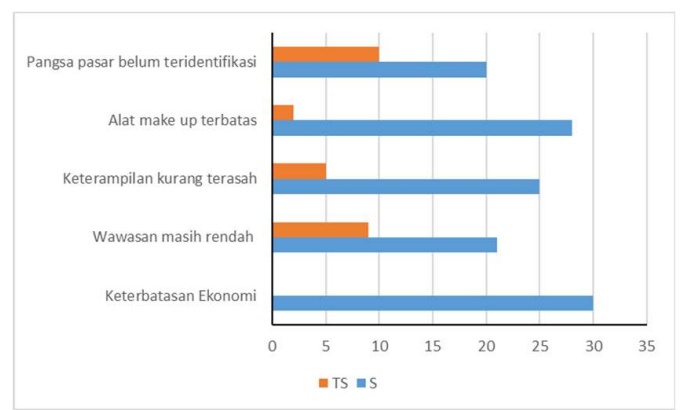

Gambar 4. Identifikasi kendala yang dihadapi mitra. Keterangan: TS: Tidak Setuju, S: Setuju.

Pada tabel 1 program pengabdian pelatihan kewirausahaan rias pengantin dihadiri sebanyak 30 santriwati di aula pondok posenatren. Berdasarkan santriwati yang hadir diwakili pada berbagai tingkat pendidikan mulai dari MI, MTS, dan MA. Untuk meningkatkan peran dan keberlanjutan program selanjutnya maka tim berusaha menggali kendala dengan mengidentifikasi masalah yang dihadapi oleh santri ketika membuka peluang usaha kewirausahaan rias pengantin. Merujuk pada gambar 4 hasil survei menggunakan kuisioner bahwa masalah ekonomi menjadi masalah utama dalam melakukan usaha rias pengantin. Tentunya hal tersebut berkaitan dengan modal dalam memulai sebuah usaha.

\section{SIMPULAN}

Berdasarkan hasil dari pengabdian kepada masyarakat dari hibah Program Pengabdian
p-ISSN: 2460-5514

e-ISSN: 2502-6518

Kemitraan (PPK) antara Universitas Jember dengan Pondok Pesantren Miftahul Ulum maka ada beberapa simpulan yang bisa diperoleh yaitu: 1) pengetahuan dan keterampilan santri putri menjadi terasah ketika diberikan pendampingan dan praktek tata rias pengantin, 2) menumbuhkan jiwa wirausaha berbasis keterampilan diri dalam hal tata rias pengantin, 3 ) dapat menjadi usaha (start up) untuk kalangan sendiri baik dalam lingkup pesantren dan masyarakat sekitar.

\section{Ucapan Terima Kasih}

Tim pelaksana pengabdi mengucapkan terima kasih kepada LP2M Universitas Jember berdasarkan SPK Pelaksana Pengabdi dengan Nomor 2603/UN25.3.2/PM/2020 Tanggal 14 Agustus 2020.

\section{DAFTAR PUSTAKA}

Haryono, A. 2019. Panduan Potong Rambut Dan Kewirausahaannya. Jember: Universitas Jember.

Machsum, T. (2013). Identitas dalam Sastra Pesantren di Jawa Timur. Jurnal Pendidikan Dan Kebudayaan, 19(3), 407. https://doi.org/10.24832/jpnk.v19i3.300

Ryandono, M. N. H. (2018). Peran Pondok Pesantren dalam Pemberdayaan Sosial Ekonomi di Jawa Timur pada Abad ke-20. Mozaik Humaniora, 18(2), 189-204.

Sayono, J. (2005). Perkembangan pesantren di jawa timur (1900-1942). Bahasa Dan Seni, 1(1), 54-69. Retrieved from http://sastra.um.ac.id/wpcontent/uploads/2009/10/PerkembanganPesantren-di-Jawa-Timur-1900-1942-JokoSayono

Widodo, S., dan T. R. D. A. Nugroho. 2014. Model Pendidikan Kewirausahaan Bagi Santri Untuk Mengatasi Pengangguran. MIMBAR, 30(2): 171-179. 